"An empirical analysis of the determinants of the U.S. banks' profitability"

\begin{tabular}{ll} 
AUTHORS & $\begin{array}{l}\text { Chiaku Chukwuogor } \\
\text { Emmanuel Anoruo } \\
\text { lkechukwu Ndu }\end{array}$ \\
\hline ARTICLE INFO & $\begin{array}{l}\text { Chiaku Chukwuogor, Emmanuel Anoruo and lkechukwu Ndu (2021). An } \\
\text { empirical analysis of the determinants of the U.S. banks' profitability. Banks and } \\
\text { Bank Systems, 16(4), 209-217. doi:doi 10.21511/bbs.16(4).2021.17 }\end{array}$ \\
\hline DOI & doi http://dx.doi.org/10.21511/bbs.16(4).2021.17 \\
\hline RELEASED ON & Monday, 27 December 2021 \\
\hline RECEIVED ON & Sunday, 04 July 2021 \\
\hline ACCEPTED ON & Friday, 17 December 2021 \\
\hline LICENSE & This work is licensed under a Creative Commons Attribution 4.0 International \\
\hline JOURNAL & License \\
\hline ISSN PRINT & "Banks and Bank Systems" \\
\hline ISSN ONLINE & $1816-7403$ \\
\hline PUBLISHER & $1991-7074$ \\
\hline FOUNDER & LLC “Consulting Publishing Company "Business Perspectives" \\
\hline
\end{tabular}

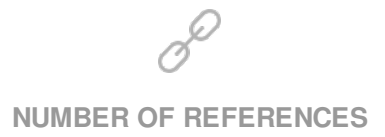

24

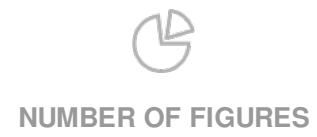

0
$= \pm=$

NUMBER OF TABLES

4

(C) The author(s) 2022. This publication is an open access article. 


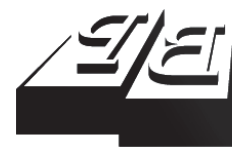

BUSINESS PERSPECTIVES

(O)

LLC "CPC "Business Perspectives" Hryhorii Skovoroda lane, 10, Sumy, 40022, Ukraine www.businessperspectives.org

Received on: $4^{\text {th }}$ of July 2021 Accepted on: $17^{\text {th }}$ of December 2021 Published on: 27 $7^{\text {th }}$ of December, 2021

(C) Chiaku Chukwuogor, Emmanuel Anoruo, Ikechukwu Ndu, 2021

Chiaku Chukwuogor, Ph.D., Professor of Finance and Banking, Department of Economics and Finance, Eastern Connecticut State University, U.S.A. (Corresponding author)

Emmanuel Anoruo, Ph.D., Professor of Economics and Finance, Department of Accounting, Data Science and Management Information Systems, COPPIN State University, U.S.A.

Ikechukwu Ndu, Ph.D., Assistant Professor of Accounting, Department of Accounting, University of Southern Maine, U.S.A.

\title{
AN EMPIRICAL ANALYSIS OF THE DETERMINANTS OF THE U.S. BANKS' PROFITABILITY
}

\begin{abstract}
This study investigates the determinants of the profitability of U.S. banks. Employing quarterly data, this paper further examines the historical and recent trends for all U.S. banks from 1996 to 2019 in the relationship between return and assets (ROA) and other bank internal (or endogenous) profitability contributors such as net interest margin (NIM), loan loss reserves, ratio of non-performing loans to gross loans, and external (or exogenous) macroeconomic variables, such as the 30-year average mortgage rate, Gross Domestic Product (GDP) economic growth rate, unemployment rate, interest rate, inflation rate and openness (i.e., exports + imports/GDP) by using the Generalized Method of Moments (GMM) estimator technique. The results reveal that bank-specific variables, including net interest margin, loan loss reserves and non-performing loans, have a significant impact on bank profitability in the United States. Similarly, the results show that macroeconomic variables, namely the average mortgage rate, economic growth, and unemployment rate, exert significant effects on the U.S. banks' profitability. The results further indicate that changes in openness are detrimental to bank profitability. The implications are discussed.
\end{abstract}

Keywords

JEL Classification

\section{INTRODUCTION}

U.S. banks serve as one of the important vehicles that channel funds from saving units to investing units in the financial system. A successful flow of investments to households, corporations and individual investors in the U.S.A. depends heavily on a healthy banking sector. During the U.S. financial crisis, there was a near collapse of the financial system because of irregular lending practices by U.S. banks in the real estate sector. Just as the banking sector seemed to have recovered from the financial crisis, the COVID-19 pandemic struck a blow to the profitability of the U.S. banks. The Return on Assets (ROA) of the U.S. banks, between April 2019 and April 2020, declined from 1.33 percent to 0.34 percent, a decline of 74 percent. The U.S. GDP growth was a record low of -9 percent in the second quarter of 2020. According to the U.S. Bureau of Labor Statistics, in December 2020, the U.S. unemployment rate was 6.7 percent, almost twice the rate of 3.5 percent in February 2020. Research evidence pointed to macroeconomic (exogenous) variables as some of the important determinants of bank profitability. Despite the measures taken during the financial crisis and aftermath to address issues that could negatively affect U.S. banks' profitability and risk, these new developments deserve further investigation.

According to traditional banking reasoning, there should be a strong positive correlation between net interest margin (NIM) and the summary profit ratio ROA. NIM shows the average earnings assets con- 
tribution to investment income after deduction of interest expenses. In addition, conventional banking reasoning indicates that increases in Loan Loss Provision signal a decline in bank profitability, at least as perceived by the management of a bank. Some exogenous variables, such Gross Domestic Product (GDP) growth rates, unemployment rates, interest rates and inflation rates, have expected relations with ROA. For example, high GDP growth rates are associated with increased ROA, while declining GDP growth rates are associated with declining ROA. This is because a rise in GDP growth rates is usually accompanied by increased individual income, business prosperity and even governments' optimism and increased fiscal expenditure. All these will lead to increased spending and investments. On the other hand, low unemployment rates are associated with declining ROA. Both GDP growth and unemployment rates impact the ROA of banks. This should not be surprising, given that the two series have implications for economic activity that are consequential to banks interest and non-interest incomes. Interest rates are also important because generally the lower the interest rate will be when more businesses and individuals patronize bank loans for investment purposes and refinancing of homes etc. For most banks, loans constitute about 70 percent of their assets. Hence the importance of interest income and net interest income. The level of bank expenses will impact bank profitability. Many banks, especially large banks, in recent years, have intensified their effort to increase their net non-interest income, that is income derived primarily from fees and other banks' income earning activities that are non-loan related.

There are studies on U.S. bank profitability and determinants of bank profitability, but no study, to the researchers' knowledge, has used all of the variables in this research. This study investigates the relationship between return on assets (ROA) and other bank internal (or endogenous) profitability contributors such as net interest margin (NIM), loan loss reserves, ratio of non-performing loans to gross loans, and external (or exogenous) macroeconomic variables, such as the 30 -year average mortgage rate, GDP economic growth rate, unemployment rate, interest rate, inflation rate and openness by using the Generalized Method of Moments (GMM) estimator technique.

The rest of the paper is structured as follows. Following this introduction, section 1 presents the literature review. Section 2 describes the data and descriptive statistics. Section 3 articulates the methodologies of the study. Section 4 performs an analysis of the empirical results. The last section discusses the conclusions of the study.

\section{LITERATURE REVIEW}

Bank profitability is the excess of bank revenue over the costs used to produce such revenue. For ease of comprehension or comparison, this amount can be expressed as a percentage of the bank's total assets or total equity. This study will focus on the profit definition of net bank revenue expressed as a percent of total assets (ROA), because using total equity as a denominator will lead to extensive risk analysis, which this study is not focused on.

Kosmidou et al. (2005) investigated the effects of bank characteristics, macroeconomic conditions, and financial market structure on net interest margin (NIM) and return on average assets (ROAA) in the United Kingdom commercial banking industry from 1995 to 2002 . They found that the ratio of cost to income is negative and statistically significant in all the cases. They further found that liquidity was negatively related to NIM and positively related to ROAA. In addition, they found that loan loss reserves have a significantly positive effect on NIM whether or not bank characteristics are considered alone. Based on this finding, they concluded that higher risks engender higher margins. Their results further revealed that the relationship between size and performance is only significant in the case of NIM. Regarding macroeconomic variables, the authors found that both inflation and GDP growth rate have a significantly positive effect on bank performance. Lastly, they found that the proxies for banking industry development and the stock market have a significantly positive influence on performance, regardless whether NIM or ROAA is the independent variable. 
There seems to be an absence of literature on studies that have focused on the traditional linkages of ROA and fundamental contributors to profit such as interest margin, non-interest margin, provision for loan losses and expenses. Most of the earlier studies on bank profitability relied on a panel data approach. However, this study uses aggregate data on bank specific and macroeconomic variables to explore the determinants of bank profitability. This study adopts the GMM estimator technique, since unlike the standard OLS (Ordinary Least Squares), it can correct for endogeneity and heteroscedasticity that might be present between the variables in the model.

There is evidence that trade openness is a determinant of profitability of U.S. banks. Ashraf et al. (2017) found that trade openness can impact bank risk-taking both adversely and favorably. There is supporting literature that sectors that are more amalgamated with the international markets benefit from international diversification and are less affected by domestic financial conditions (Braun \& Raddatz, 2007; Wagner, 2013; Luo et al., 2016). Firms that engage in international trade exhibit higher productivity and greater survival chances than non-participating firms (Wagner, 2012). Rahman et al. (2020) found that higher trade openness lowers bank risk-taking both in the short and long run.

This paper contributes to the literature in several ways. Unlike the earlier studies on the determinants of banks profitability in the United States, the present study applies a theoretical consistent methodology of the GMM system estimator. In addition, the study employs longer time series on the mortgage rate, economic growth rate, inflation rate, loan loss reserves, ratio of non-performing loans to gross loans, net interest margin, openness, return on assets and unemployment rate variables. Further, the study introduces openness as a possible determinant of bank profitability, given that most banks are now operating in a global economy.

\section{DATA AND DESCRIPTIVE STATISTICS}

This study employs quarterly data on the 30 -year average mortgage rate, economic growth, inflation rate, loan loss reserves, ratio of non-performing loans to gross loans, net interest margin, openness (exports + imports/GDP), return on assets and unemployment rate variables. Data were sourced from the U.S. Call Report Data and Uniform Bank Performance Reports, Reports of Condition and Income for All Insured U.S. Commercial Banks, Federal Reserve Bank of St. Louis and World Bank and several banks and financial institutions' websites.

Table 1 displays the descriptive statistics for the 30 -year average mortgage rate, economic growth, inflation rate, loan loss reserves, ratio of non-performing loans to gross loans, net interest margin, openness, return on assets and unemployment rate variables. The mean values for the 30 -year average mortgage rate, economic growth rate, inflation rate, loan loss reserves, net interest margin, non-performing loans, openness, return of assets and unemployment rate variables are 5.49, $2.3,0.51,1.82,3.55,1.84,27.54,1.07$ and 5.86 percent, respectively. Openness posted the highest mean value of 27.54 percent, while inflation rate exhibited the lowest mean value of 0.53 percent. The minimum and maximum statistics reported in Table 1 reveal that the values of the various series have changed over the sample period. For instance, the minimum and maximum values for unemployment rate ranged from a low of 3.60 to 13.33 percent. Openness (3.48\%) displayed the highest standard deviation, while return on assets $(0.36 \%)$ posted the least. The Chicago Board Options Exchange Volatility Index (VIX) has a standard deviation of 7.96 percent. Economic growth rate, inflation rate, openness and return on assets are negatively skewed, while average mortgage rate, loan loss reserves, net interest margin, non-performing loans and unemployment rate are positively skewed. The kurtosis statistics for economic growth rate, inflation rate, loan loss reserves, non-performing loans, return on assets, and unemployment rate exceed 3, suggesting that these series are not normally distributed. However, the Jarque-Bera statistics reveal that the null hypothesis that average mortgage rate, economic growth rate, inflation rate, loan loss reserves, net interest margin, non-performing loans, openness, return of assets and unemployment rate variables are normally distributed should be rejected at least at the 5 percent level of significance. 
Table 1. Descriptive statistics

\begin{tabular}{|c|c|c|c|c|c|c|c|c|c|}
\hline Statistic & AMR & GR & INF & LLR & NIM & NPL & OPN & ROA & UR \\
\hline Mean & 5.49 & 2.30 & 0.53 & 1.82 & 3.55 & 1.84 & 27.54 & 1.07 & 5.86 \\
\hline Median & 5.71 & 2.50 & 0.53 & 1.73 & 3.47 & 1.20 & 28.08 & 1.21 & 5.30 \\
\hline Maximum & 8.32 & 5.30 & 2.20 & 3.70 & 4.38 & 5.64 & 32.24 & 1.41 & 13.33 \\
\hline Minimum & 2.94 & -9.00 & -2.83 & 1.15 & 2.80 & 0.70 & 20.27 & -0.10 & 3.60 \\
\hline Std. dev. & 1.48 & 2.11 & 0.64 & 0.60 & 0.40 & 1.36 & 3.48 & 0.36 & 1.91 \\
\hline Skewness & 0.18 & -2.26 & -1.33 & 1.38 & 0.36 & 1.50 & -0.33 & -1.57 & 1.33 \\
\hline Kurtosis & 1.79 & 11.16 & 9.73 & 4.48 & 2.15 & 3.93 & 1.79 & 4.83 & 4.42 \\
\hline Jarque-Bera & $6.63^{* *}$ & $358.58^{* * *}$ & $216.07^{* * *}$ & $40.33^{* * *}$ & $5.11^{*}$ & $40.68^{* * *}$ & $7.77^{* *}$ & $54.80^{* * *}$ & $37.58^{* * *}$ \\
\hline Probability & 0.04 & 0.00 & 0.00 & 0.00 & 0.08 & 0.00 & 0.02 & 0.00 & 0.00 \\
\hline Observations & 99.00 & 99.00 & 99.00 & 99.00 & 99.00 & 99.00 & 99.00 & 99.00 & 99.00 \\
\hline
\end{tabular}

Note: ${ }^{* * *},{ }^{* *}$, and ${ }^{*}$ indicate rejection of the normality assumption at the $1 \%, 5 \%$ and $10 \%$ levels of significance, respectively; $\mathrm{AMR}=$ Average mortgage interest rate; $\mathrm{GR}=\mathrm{GDP}$ growth rate; INF = Inflation rate; $\mathrm{LLR}=\mathrm{Loan}$ loss reserves; $\mathrm{NPL}=$ the ratio of non-performing loans to gross loans; NIM = Net interest margin; OPN = Openness measure (i.e., exports + imports /GDP); ROA = Return on assets; UR = Unemployment rate.

Table 2 displays the pairwise Pearson correlation coefficients between the average mortgage rate, economic growth rate, inflation rate, loan loss reserves, net interest margin, non-performing loans, openness, return of assets and unemployment rate variables. The correlation coefficients between return on assets and the other variables are statistically significant at least at the 10 percent level. The highest correlation coefficient (0.87) is between non-performing loans and loan loss reserves. However, the least correlation coefficient $(-0.08)$ is reported between loan loss reserves and average mortgage rate. The Pearson correlation coefficients have provided a cursory evidence of the associations between return on assets and the other variables. However, to gain a deeper understanding, a more rigorous econometric model such as the GMM is required.

\section{METHODOLOGY}

The empirical analysis combines bank specific dependent variables such as the net interest margin (NIM), loan loss reserves, and macroeconomic variables, such as Gross Domestic Product (GDP) growth rates, unemployment rates, interest rates and inflation rates, using the Generalized Method of Moments (GMM) estimator. In particular, the study used the modified Dickey-Fuller unit root to determine the time series properties of the variables in the model. The modified Dickey-Duller (DF-GLS) technique has been documented in the literature to possess better power than the standard Dickey-Fuller (Elliot et al., 1996). The DF-GLS unit root test is based on the following regression equation:

$$
\Delta X_{t}^{k}=\alpha_{0} X_{t-1}^{k}+\sum_{j=1}^{m} \alpha_{j} \Delta X_{t-j}^{k}+\varepsilon t
$$

Table 2. Pearson correlation coefficients

\begin{tabular}{|c|c|c|c|c|c|c|c|c|c|}
\hline Series & AMR & GR & INF & LLR & NIM & NPL & OPN & ROA & UR \\
\hline AMR & 1.00 & - & - & - & - & - & - & - & - \\
\hline GR & $0.41^{* * *}$ & 1.00 & - & - & - & - & - & - & - \\
\hline INF & $0.19^{*}$ & $0.22^{*}$ & 1.00 & - & - & - & - & - & - \\
\hline LLR & -0.08 & $-0.31^{* * *}$ & -0.07 & 1.00 & - & - & - & - & - \\
\hline NIM & $0.83^{* * *}$ & $0.48^{* * *}$ & 0.13 & $0.21^{* *}$ & 1.00 & - & - & - & - \\
\hline NPL & $-0.40^{* * *}$ & $-0.34^{* * *}$ & -0.11 & $0.87^{* * *}$ & -0.16 & 1.00 & - & - & - \\
\hline OPN & $-0.85^{* * *}$ & $-0.22^{*}$ & -0.09 & -0.12 & $-0.86^{* * *}$ & $0.30^{*}$ & 1.00 & - & - \\
\hline ROA & $0.39^{* * *}$ & $0.67^{* * *}$ & $0.20^{*}$ & $-0.65^{* * *}$ & $0.39^{* * *}$ & $-0.69^{* * *}$ & $-0.28^{* *}$ & 1.00 & - \\
\hline UR & $-0.39^{* * *}$ & $-0.58^{* * *}$ & -0.14 & $0.84^{* * *}$ & -0.17 & $0.82^{* * *}$ & 0.12 & $-0.68^{* * *}$ & 1.00 \\
\hline
\end{tabular}

Note: ${ }^{* * *},{ }^{* *}$, and ${ }^{*}$ indicate $1 \%, 5 \%$ and $10 \%$ levels of significance, respectively; AMR = Average mortgage interest rate; $\mathrm{GR}=$ GDP growth rate; INF = Inflation rate; LLR = Loan loss reserves; NPL = the ratio of non-performing loans to gross loans; $\mathrm{NIM}=$ Net interest margin; OPN = Openness measure; ROA = Return on assets; UR = Unemployment rate. 
where $X$ is the variable of interest; $m$ represents the maximum lag, and $X_{t}^{k}$ indicates the locally detrended series of $X_{t}$.

The study uses the modified Akaike Information Criterion advanced by $\mathrm{Ng}$ and Perron (2002) to determine the optimal lags for all of the variables in the model. The null hypothesis of the DF-GLS unit root test is $\alpha_{0}=0$. However, the alternative hypothesis is $a_{0}<0$. The study next implements the Generalized Method of Moments (GMM) system estimator technique to underpin the effects of average mortgage rate, economic growth, inflation rate, loan loss reserves, net interest margin, non-performing loans, changes in openness and unemployment rate on bank profitability. The model is based on the following expression:

$$
R O A=f\left(\begin{array}{l}
A M R, G R, I N F, L L R, \\
N P L, N I M, O P N, U R
\end{array}\right)
$$

For econometric purposes, equation (2) is rewritten as follows:

$$
\begin{aligned}
& R O A_{t}=\beta_{0}+\beta_{1} A M R_{t}+\beta_{2} G R_{t}+\beta_{3} I N F_{t}+ \\
& +\beta_{4} L L R_{t}+\beta_{5} N P L_{t}+\beta_{6} N I M_{t}+ \\
& +\beta_{7} O P N_{t}+\beta_{8} R U R_{t}+\varepsilon_{t},
\end{aligned}
$$

where $R O A$ represents return on assets (proxy for bank profitability), $A M R$ is the average mortgage rate, GR stands for GDP growth rate, INF represents inflation rate, $L L R$ stands for loan loss reserves, NPL is the ratio of non-performing loans to gross loans, NIM is the net interest margin, OPN is the measure of openness (i.e., exports + imports /GDP), and $U R$ is the unemployment rate. In equation (3), $\beta_{1} \ldots$ $\beta_{8}$ are the coefficient estimators of the independent variables and $\varepsilon$ represents the error term.

\section{EMPIRICAL RESULTS}

The empirical results of the study are discussed in this section. Table 3 presents the results from the modified augmented Dickey-Fuller (DF_GLS) unit root test. The lag lengths for the unit root tests were determined via the Modified Akaike Information Criterion (MAIC). The results indicate that average mortgage rate, economic growth rate, inflation rate, loan loss reserves, net interest margin, non-performing loans, return of assets and unemployment rate are found level stationary. The test statistics $-3.06,-3.48,-10.73,-3.30$, $-2.92,-2.80,-2.87$ and -2.91 , respectively for average mortgage rate, economic growth rate, inflation rate, loan loss reserves, net interest margin, non-performing loans, return of assets and unemployment rate exceed the critical value $(-2.75)$ at the 5 percent level. In each of these cases, the null hypothesis of a unit root is rejected as the test statistics are greater than the critical values at the conventional levels. However, the result shows that the openness variable is first difference stationary. Taken together, the unit root test results indicate that average mortgage rate, economic growth rate, inflation rate, loan loss reserves, net interest margin, non-performing loans, return of

\begin{tabular}{|c|c|c|c|c|c|c|}
\hline Series & Level & Difference & $\mathbf{k}$ & $1 \% \mathrm{CV}$ & $5 \% \mathrm{CV}$ & $10 \% \mathrm{CV}$ \\
\hline AMR & $-3.06^{* *}$ & - & 1 & -3.59 & -3.04 & -2.75 \\
\hline GR & $-3.48^{* * *}$ & - & 0 & -3.59 & -3.04 & -2.75 \\
\hline INF & $-10.73^{* * *}$ & - & 1 & -3.59 & -3.04 & -2.75 \\
\hline LLR & $-3.30^{* *}$ & - & 3 & -3.59 & -3.04 & -2.75 \\
\hline NIM & $-2.92^{*}$ & - & 2 & -3.59 & -3.04 & -2.75 \\
\hline NPL & $-2.80^{*}$ & - & 2 & -3.59 & -3.04 & -2.75 \\
\hline OPN & -2.17 & -4.51 & 2 & -3.59 & -3.04 & -2.75 \\
\hline ROA & $-2.87^{*}$ & - & 4 & -3.59 & -3.04 & -2.75 \\
\hline UR & $-2.91^{*}$ & - & 0 & -3.59 & -3.04 & -2.75 \\
\hline
\end{tabular}
assets and unemployment rate are level stationary, while openness is first level stationary.

Table 3. Modified Dickey-Fuller unit root tests

Note: ${ }^{* * *},{ }^{* *}$, and ${ }^{*}$ indicate rejection of the null hypothesis of a unit root at the $1 \%, 5 \%$ and $10 \%$ levels, respectively. The modified Akaike Information Criterion was used to determine the lag lengths. The null hypothesis is the series has a unit root. $A M R=$ Average mortgage interest rate, $\mathrm{GR}=\mathrm{GDP}$ growth rate, INF = Inflation rate, $\mathrm{K}=$ Lag lengths, $\mathrm{LLR}=$ Loan loss reserves, $\mathrm{NPL}=$ the ratio of nonperforming loans to gross loans, NIM $=$ Net interest margin, OPN = Openness measure (i.e., exports + imports /GDP), $\mathrm{ROA}=$ Return on assets, UR = Unemployment rate.

Having determined the order of integration for the various variables in the model, the study next implements the GMM estimator to ascertain the effects of bank-specific and macroeconomic variables on the profitability of banks. The lagged values of the variables served as instruments for the GMM estimator. To assess the suitability of these instruments in the model, the study applied the $J$-statistic also known as the over-identifying restrictions test. The J-statistic $(5.18, p$-value $=0.82)$ presented in Panel B of Table 4 suggests that the chosen instruments are valid. The coefficient estimators from the GMM are presented in Panel A of 
Table 4. The results reveal that average mortgage rate, as expected, has a significantly negative effect on bank profitability. The coefficient estimator of $\mathrm{AMR}_{\mathrm{t}}$ (coef. $=-0.07, t$-stat $=-3.88, p$-value $\left.=0.00\right)$ is negative and statistically significant at the $1 \%$ level. A one percentage increase in average mortgage rate reduces bank profitability by approximately 7\%. This finding contradicts Khan and Sattar (2014) who found a positive relationship between interest rate and profitability for four major commercial banks in Pakistan. The differences in results could be attributed to the methodologies the studies adopted. In addition, the diverging results could be attributable to different economic environment and different financial regulations, especially with respect to the resources available for residents in the U.S. to obtain mortgages, such as FHA and Veteran mortgages in the U.S., resulting in a more robust real estate investment environment that is conducive to the profitability of banks.

The results presented in Table 4 further show that economic growth garners bank profitability, given that the coefficient estimator of $\mathrm{GR}_{\mathrm{t}}$ (coef. $=0.08$, $t$-stat $=4.14, p$-value $=0.00)$ is positive and statistically significant at the $1 \%$ level. Similarly, inflation appears to promote bank profitability. The coefficient estimator of $\mathrm{INF}_{t}$ (coef. $=0.07, t$-stat $=2.21, p$-value $=0.03)$ is positive and statistically significant at the $5 \%$ level. A percentage increase in inflation boosts bank profitability by roughly $8 \%$. The finding of a positive relationship between economic growth and profitability is at odds with Issah and Antwi (2017) who found for UK firms that economic growth negates ROA as a measure of profitability. However, loan loss reserves have a detrimental impact on bank profitability. The coefficient estimator of $\operatorname{LLR}_{t}$ (coef. $=-1.15, t$-stat $=$ $-11.95, p$-value $=0.00)$ shows that a unit increase in loan loss reserves reduces bank profitability by approximately 1.15 units. The finding that loan loss reserves negate bank profitability is consistent with Ramlall (2009), Vong (2005), Miller and Noulas (1997), and Sufian and Habibullah (2009).

Based on the results reported in Table 4, net interest margin has a significantly positive effect on bank profitability. The coefficient estimator of NIM $_{\mathrm{t}}$ (coef. $=1.05, t$-stat $=10.76$, $p$-value $\left.=0.00\right)$ is positive and statistically significant at the $1 \%$ lev- el. A unit increase in net interest margin engenders bank profitability by roughly 1.05 units. Nonperforming loans exert a positive impact on bank profitability.

The coefficient estimator of NPL (coef. $=0.11$, $t$-stat $=2.35, p$-value $=0.02)$ is positive and statistically significant at the $5 \%$ level. A percentage increase in non-performing loans boosts bank profitability by roughly $11 \%$. The positive effect of non-performing loans on bank profitability is expected because when profitability is high, banks tend to increase their loan loss provision as a buffer for worse conditions that may ensue in the future and vice versa. This finding is consistent with Ndu and Chukwuogor (2021) who found a highly significant positive relationship between loan loss provisions and the Total Capital Risk Adequacy solvency ratio for a sample of listed US commercial banks, thus indicating the existence of earnings management using non-performing loans. Likewise, Ndu and Chukwuogor (2021) agree with the observation of this paper that non-performing loans have a positive impact on bank profitability via opportunistic earnings management practiced by the bank management.

The results displayed in Table 4 also reveal that changes in openness have a negative effect on bank profitability. The coefficient estimator of $\Delta \mathrm{OPN}_{\mathrm{t}}$ (coef. $=-0.28, t$-stat $=-3.60, p$-value $=$ 0.00 ) is negative and statistically significant at the $1 \%$ level. This result indicates that a $1 \%$ increase in the degree of openness negates bank profitability by approximately $28 \%$. This finding is not surprising, given that openness promotes competition from foreign banks in the United States. Finally, the results in Table 4 show that unemployment has a positive effect on bank profitability. The coefficient estimator $\mathrm{UR}_{\mathrm{t}}$ (coef. $=0.18, t$-stat $=5.23$, $p$-value $=0.00)$ is positive and statistically significant at the $1 \%$ level. Taken together, the results from the GMM estimator indicate that average mortgage rate, loan loss reserves, and changes in openness have detrimental effects on bank profitability. However, economic growth, inflation, non-performing loans, and unemployment beget bank profitability in the United States. The coefficient of determination $\left(\mathrm{R}^{2}=0.79\right)$ suggests that the model explained approximately $79 \%$ of the variation in bank profitability. 
Table 4. GMM estimation results (dependent variable: ROA)

\begin{tabular}{|c|c|c|c|c|}
\hline \multicolumn{5}{|c|}{ Panel A: estimation results } \\
\hline Variable & Coefficient & Std. error & t-statistic & Prob. \\
\hline C & $-1.64^{* * *}$ & 0.26 & -6.37 & 0.00 \\
\hline AMR & $-0.07^{* * *}$ & 0.02 & -3.88 & 0.00 \\
\hline GR & $0.08^{* * *}$ & 0.02 & 4.14 & 0.00 \\
\hline INF & $0.07^{* *}$ & 0.03 & 2.21 & 0.03 \\
\hline LLR & $-1.15^{* * *}$ & 0.10 & -11.95 & 0.00 \\
\hline NIM & $1.05^{* * *}$ & 0.10 & 10.76 & 0.00 \\
\hline NPL & $0.11^{* *}$ & 0.05 & 2.35 & 0.02 \\
\hline$\triangle \mathrm{OPN}$ & $-0.28^{* * *}$ & 0.08 & -3.60 & 0.00 \\
\hline UR & $0.18^{* * *}$ & 0.04 & 5.23 & 0.00 \\
\hline \multicolumn{5}{|c|}{ Panel B: diagnostic tests } \\
\hline R-squared & 0.79 & \multicolumn{2}{|c|}{ J-statistic } & 5.18 \\
\hline Adjusted R-squared & 0.77 & \multicolumn{2}{|c|}{ Prob. (J-statistic) } & 0.82 \\
\hline Durbin-Watson stat & 1.79 & \multicolumn{2}{|c|}{ - } & - \\
\hline
\end{tabular}

Note: ${ }^{* * *},{ }^{* *}$, and ${ }^{*}$ indicate level of significance at the $1 \%, 5 \%$ and $10 \%$, respectively. AMR $=$ Average mortgage interest rate, GR $=\mathrm{GDP}$ growth rate, $\mathrm{INF}=$ Inflation rate, $\mathrm{LLR}=$ Loan loss reserves, $\mathrm{NPL}=$ non-performing loans to gross loans, $\mathrm{NIM}=$ Net interest margin, $\triangle \mathrm{OPN}=$ Changes in openness measure, ROA = Return on assets, UR = Unemployment rate.

\section{CONCLUSIONS}

This paper has examined the determinants of bank profitability in the United States for the period spanning 1996 quarter 1 through to 2019 quarter 4. Specifically, the study used the modified augmented Dickey-Fuller (DF_GLS) unit root test to determine the time series properties of average mortgage rate, economic growth, inflation rate, loan loss reserves, net interest margin, non-performing loans, changes in openness, return on assets and unemployment rate. The GMM estimator technique was employed to ascertain the effects of the independent variables on bank profitability proxied by ROA. To assess the validity of the instruments used for the GMM estimator model, the study applied the J-Statistic. The unit root test results obtained from the DF_GLS revealed that the average mortgage rate, economic growth, inflation rate, loan loss reserves, net interest margin, non-performing loans, changes in openness, return on assets and unemployment rate are level stationary. In other words, these variables have zero order of integration. However, the results indicate that openness exhibits one order of integration and hence changes in openness were used in the estimation of the GMM model. Based on the result from the J-statistic, it was concluded that the instruments used in the estimation of the GMM model were valid. The results from the GMM estimator model reveal that the average mortgage rate, loan loss reserves, and changes in openness have a significantly negative influence on bank profitability. However, the results indicate that economic growth, inflation rate, net interest margin, non-performing loans, and unemployment rate have a significantly positive impact on bank profitability in the United States. Taken together, the results from this study overwhelmingly support the notion that both the bank-specific and macroeconomic variables are consequential to bank profitability in the United States. The findings of this study will be helpful to policymakers and bank mangers alike, as they stride to gain an understanding of the key factors that determine the profitability of commercial banks in the United States. From a policy perspective, this understanding will enable policymakers to formulate and implement policies that are conducive to commercial bank profitability.

\section{AUTHOR CONTRIBUTIONS}

Conceptualization: Chiaku Chukwuogor.

Data curation: Chiaku Chukwuogor, Emmanuel Anoruo, Ikechukwu Ndu.

Formal analysis: Emmanuel Anoruo, Ikechukwu Ndu. 
Funding acquisition: Chiaku Chukwuogor.

Investigation: Chiaku Chukwuogor.

Methodology: Chiaku Chukwuogor, Ikechukwu Ndu.

Project administration: Chiaku Chukwuogor.

Resources: Chiaku Chukwuogor.

Software: Emmanuel Anoruo.

Supervision: Chiaku Chukwuogor, Emmanuel Anoruo.

Validation: Chiaku Chukwuogor, Ikechukwu Ndu.

Visualization: Chiaku Chukwuogor, Emmanuel Anoruo, Ikechukwu Ndu.

Writing - original draft: Chiaku Chukwuogor, Emmanuel Anoruo, Ikechukwu Ndu.

Writing - reviewing \& editing: Chiaku Chukwuogor, Emmanuel Anoruo, Ikechukwu Ndu.

\section{REFERENCES}

1. Afanasieff, T., Lhacer P., \& Nakane, M. (2001). The Determinants of Bank Interest Spreads in Brazil. Joint Research of the Central Bank of Brazil and the University of Sao Paulo. Retrieved from https://citeseerx.ist.psu.edu/viewdoc/downlo $\mathrm{ad}$.doi=10.1.1.522.3006\&rep=rep1 \&type $=\mathrm{pdf}$

2. Agu, C. C. (1992). Analysis of the Determinants of the Nigerian Banking System's Profits and Profitability Performance. Savings and Development, 16(4), 353-369. Retrieved from https://www.jstor. org/stable/25830315

3. Ashraf, B. N., Arshad, S., \& Liang, Y. (2017). Trade Openness and Bank Risk-Taking Behavior: Evidence from Emerging Economies. Journal of Risk and Financial Management, 10(3), 15. https://doi.org/10.3390/ jrfm10030015

4. Braun, M., \& Raddatz, C. (2007). Trade liberalization, capital account liberalization and the real effects of financial development. Journal of International Money and Finance, 26, 730-761. Retrieved from https:// papers.ssrn.com/sol3/papers. cfm?abstract_id=995320

5. Demirguc-Kunt, A., \& Huizinga, H. (2000). Financial Structure and Bank Profitability (Policy Research Working Paper No. 2430). World Bank. Retrieved from https://documents.worldbank.org/en/publication/ documents-reports/documentdetail/364151468749353823/pdf

6. Dickey, D., \& Fuller, W. (1981). The Likelihood Ratio Statistics for
Autoregressive Time Serieswith a Unit Root. Econometrica, 49(4), 1057-1072. https://doi. org/10.2307/1912517

7. Elliott, G., Rothenberg, T., \& Stock, J. (1996). Efficient Test for an Autoregressive Unit Root. Econometrica, 64(4), 813-836. https://doi.org/10.2307/2171846

8. Fu, Q., \& Heffernan, S. (2010). Determinants of financial performance in Chinese banking. Applied Financial Economics, 20(20), 1585-1600. https://doi.org/ $10.1080 / 09603107.2010 .505553$

9. Hanweck, G., \& Ryu, L. (2005). The Sensitivity of Bank Net Interest Margins and Profitability to Credit, Interest-Rate, and Term-Structure Shocks Across Bank Product Specializations (Working Paper No. 2005-02). Retrieved from https:// www.fdic.gov/bank/analytical/ working/wp05-02.pdf

10. Heggestad, A. A., \& Mingo, J. J. (1976). Prices, nonprice and concentration in commercial. Banking. Journal of Money, Credit and Banking, 8(1), 107-l17. https:// doi.org/10.2307/1991923

11. Issah, M., \& Antwi, S. (2017). Role of macroeconomic variables on firms' performance: Evidence from the UK. Cogent Economics and Finance, 5(1), 1405581. https://doi.org/10.1080/23322039. 2017.1405581

12. Khan, W. A., \& Sattar, A. (2014). Impact of Interest Rate Changes on the Profitability of four Major Commercial Banks in Pakistan.
International Journal of Accounting and Financial Reporting, 4(1), 142154. https://doi.org/10.5296/ijafr. v4i1.5630

13. Kosmidou, K., Tanna, S., \& Pasiouras, F. (2005). Determinants of Profitability of Domestic UK Commercial Banks: Panel Evidence from the Period 1995-2002 (Economics, Finance and Accounting Applied Research Working Paper Series No. RP08-4). Coventry: Coventry University. Retrieved from http://repec.org/ mmfc05/paper45.pdf

14. Lartey, V. C., Antwi, S., \& Kofi, B. F. (2013). The Relationship between Net Interest Margin and Return on Assets of Listed Banks in Ghana. Research Journal of Finance and Accounting, 4(16) 73-79. Retrieved from https:// www.iiste.org/Journals/index.php/ RJFA/article/view/8287

15. Luo, Y., Tanna, S., \& De Vita, G. (2016). Financial openness, risk, and bank efficiency: Cross-country evidence. Journal of Financial Stability, 24, 132148. https://doi.org/10.1016/j. jfs.2016.05.003

16. Miller, S. M., \& Noulas, A. G. (1997). Portfolio mix and large-bank profitability in the USA. Applied Economics, 24(4), 505-512. https://doi org/10.1080/000368497326994

17. Ndu, I., \& Chukwuogor, C. (2021). Modelling Earnings Management, Corporate Governance, Capital Management and Risk Using Dynamic Panel Data Estimation: 
The Case of Listed Commercial Banks in the United States (Working Research Paper). Presented at the 50th NEDSI Annual Conference (virtual). United States.

18. Ng, S. \& Perron, P. (2002). PPP May not Hold Afterall: A Further Investigation. Annals of Economics and Finance, 3, 43-64. Retrieved from http://www.columbia. edu/ sn2294/pub/annals02.pdf

19. Rahman, M. M., Begum, M., Ashraf, B. N., \& Masud, Md. A. K. (2020). Does Trade Openness Affect Bank Risk-Taking Behavior? Evidence from BRICS Countries. Economies, 8(3), 75. https://doi. org/10.3390/economies8030075
20. Ramlall, I. (2009). BankSpecific, Industry-Specific and Macroeconomic Determinants of Profitability in Taiwanese Banking System: Under Panel Data Estimation. International Research Journal of Finance and Economics, $34,160-167$

21. Sufian, F., \& Habibullah, M. S. (2009). Determinants of bank profitability in a developing economy: Empirical evidence from Bangladesh. Journal of Business Economics and Management, 10(3), 207-217. https://doi.org/10.3846/1611 1699.2009.10.207-217

22. Vong, L. K. (2005). Loans and Profitability of Banks in Macao.
AMCM Quarterly Bulletin, 15, 91-107. Retrieved from https:// citeseerx.ist.psu.edu/viewdoc/dow nload?doi $=10.1 \cdot 1.598 .5205 \& \mathrm{rep}=\mathrm{r}$ ep1\&type $=$ pdf

23. Wagner, J. (2012). International trade and firm performance: A survey of empirical studies since 2006. Review of World Economics, 148(2), 235-267. Retrieved from https://www.jstor.org/stable/41485795

24. Wagner, J. (2013). Exports, imports and firm survival: First evidence for manufacturing enterprises in Germany. Review of World Economics, 149(1), 113-130. Retrieved from https://www.jstor. org/stable/42636094 